\title{
CANINE EHRLICHIOSIS - A CASE REPORT
}

\author{
SCHMIDT, E.M. S. ${ }^{1}$; TESSEROLLI, G.L. ${ }^{2}$ TRANQUILIM, M.V. ${ }^{1}$; LOCATELLI-DITTRICH, R. ${ }^{1}$ \\ ${ }^{1}$ Departamento de Medicina Veterinária - Universidade Federal do Paraná; \\ ${ }^{2}$ Graduanda - Curso de Medicina Veterinária - Universidade Federal do Paraná.
}

Several especies of the genus Ehrlichia have been recognized as causing in dogs a clinical disease known as ehrlichiosis. Canine ehrlichiosis is a rickettsial disease caused by Ehrlichia canis transmitted by the brown dog tick Rhipicephalus sanguineus. Ehrlichiosis is an important infectious disease of dogs and other members of the Canidae family. Ehrlichia $s p$. is an obligate intracellular parasite that infects canine leukocytes. Diagnosis is made on the basis of sorologic tests (the indirect immunofluorescent antibody) and also by the evaluation of blood and buffycoat smears. Clinical signs of disease include fever, lethargy, anorexia, weight loss and petechial to ecchymotic hemorrhages of the skin and mucous membranes. The objective of this work is to report a case of a eight year-old, male, mixed breed dog, admitted to the UFPR Veterinary Hospital. The owner reported that the patient had vomiting and diarrhea. Blood collection was performed. The CBC showed

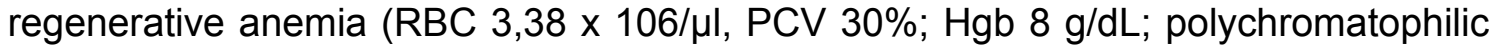
cells, Howell-jolly bodies, hypocromic cells and anisocytosis); neutrophilic leukocytosis (WBC $19.000 / \mu \mathrm{l}$; Seg neut $16.530 / \mu \mathrm{l}$; Band neut $570 / \mu \mathrm{l}$; Lymphs 1.140 $/ \mu \mathrm{l}$; Eos $190 / \mu \mathrm{l}$; Mon $570 / \mu \mathrm{l}$ ), total plasma proteins $5,2 \mathrm{~g} / \mathrm{dL}$. A morulae (an intracytoplasmatic azurophilic cluster), compatible with Ehrlichia sp, was found in a blood neutrophil from a blood cell smear stained with Wright stain. This case is being reported to alert clinicians to the possibility of occurence of canine ehrlichiosis in Curitiba - PR.

Key Words: canineEhrlichiosis 